\title{
Screening out All Valid Aristotelian Modal Syllogisms
}

\author{
Xiaojun Zhang \\ Institute of Logic and Information, Sichuan Normal University, Chengdu, China
}

\section{Email address:}

zhangxj566@163.com

\section{To cite this article:}

Xiaojun Zhang. Screening out All Valid Aristotelian Modal Syllogisms. Applied and Computational Mathematics. Vol. 8, No. 6, 2020, pp. 95-104. doi: 10.11648/j.acm.20190806.12

Received: January 5, 2020; Accepted: January 15, 2020; Published: February 13, 2020

\begin{abstract}
It is easy to understand that whether a classical syllogism is valid. That whether a modal syllogism is valid is not so transparent. The prevailing view on Aristotelian modal syllogistic is that the syllogistic is incomprehensible due to its many faults and inconsistencies. Although adequate semantic analysis or reconstruction of the syllogistic have be given by many authors, it is far from obvious how to extend these results so as to consistently cover the whole modal syllogistic developed. The major aim of this paper is to overcome these difficulties, and screen out 384 Aristotelian valid modal syllogisms from 6656 Aristotelian modal syllogisms in natural language. They can be formalized by means of set theory and generalized quantifier theory, and their validity can be proved by possible world semantics and the truth definition of Aristotelian quantifiers defined in generalized quantifier theory. The basic steps of screening out all valid Aristotelian modal syllogisms are as follows: firstly one can get all possible modal syllogisms obtained by adding modal operators to 24 valid classical syllogisms, and secondly eliminate invalid modal syllogisms by characteristic rules of modal syllogisms. It is hoped that these innovative achievements will make contributions to promote the development of Aristotelian and generalized modal syllogistic, natural language information processing, and further research on knowledge representation and knowledge reasoning in computer science.
\end{abstract}

Keywords: Generalized Quantifier Theory, Aristotelian Modal Syllogisms, Formalization, Validity, Possible Worlds

\section{Introduction}

Syllogistic reasoning is important due to the role they have played in theory and practice of reasoning from Aristotle onwards. Syllogistic reasoning is the most intensively researched in the study of logical reasoning, such as [1-10]. It is agreed that the appropriate theory of inference should be provided by formal logic, that is, by the theory of what inferences people should draw ([11], p. 192). It is easy to understand that whether a classical syllogism is valid. That whether a modal syllogism is valid is not so transparent. The prevailing view on Aristotelian modal syllogistic is that the syllogistic is incomprehensible due to its many faults and inconsistencies ([12], p. 95).

Although adequate semantic analysis or reconstruction of the syllogistic have be given by [12-18], among many others, it is far from obvious how to extend these results so as to consistently cover the whole modal syllogistic developed ([17], p. 247). Classical syllogisms has already been considered from the perspective of generalized quantifier theory, such as [19-25], but we are not aware of screening out all valid Aristotelian modal syllogisms from 6656
Aristotelian modal syllogisms in natural language. The major aim of this paper is to overcome these difficulties and prove their validity by means of generalized quantifier theory, and screen out all valid Aristotelian modal syllogisms.

Generalized quantifier theory is now standard equipment in the toolboxes of both logicians and linguists. The Aristotelian quantifiers all, some, no, not all are just four instances of generalized quantifiers [25]. Aristotelian syllogistic can be seen as a formal study of the four Aristotelian quantifiers. The syllogistic can be formalized and proved by means of generalized quantifier theory [22-23]. And then the other 22 valid classical syllogisms can be derived by means of 'Barbara' AAA-1 and 'Celarent' EAE-1 in the light of the theory [24]. It is nature that one considers to view modal syllogisms from the perspective of modern modal logic and generalized quantifier theory. The paper attempts to do this, and sets out to do what no one has succeeded in doing before: prove their validity by means of generalized quantifier theory and screen out all valid Aristotelian modal syllogisms. The following paper illustrates how these apparatus work.

In this paper, $\neg, \wedge, \Rightarrow, \Leftrightarrow, \square$, and $\diamond$ are signs of negation, conjunction, conditionality, biconditionality, necessity, and 
possibility, respectively. It is now concerned with the validity of modal syllogisms based on generalized quantifier theory, set theory and possible world semantics. Similar to classical syllogisms, a modal syllogism has two premises, one conclusion. A modal syllogism is a particular instantiation of a syllogistic scheme. One can interpret a modal syllogism such as the following example:

All animals necessarily eat something.

All dogs are animals.

Some animals possibly eat something.

The syllogism means that the sentences above the line semantically entail the one below the line. It has the form $Q_{1}(M, P) \wedge Q_{2}(S, M) \Rightarrow Q_{3}(S, P)$, where $S$ is the set of things or stuff that the subject term signifies, $P$ is the set of things or stuff that the predicate term expresses, and $M$ is the set of things or stuff that the middle term denotes, each of $Q_{1}, Q_{2}$, $Q_{3}$ in a modal syllogism is one of the following 12 generalized quantifiers all, some, no, not all, $\square$ all, $\square$ some, $\square$ no, $\square$ not all, $\diamond$ all, $\nabla_{n o}, \nabla_{\text {some }}, \nabla_{\text {not }}$ all. In the above example, $Q_{1}=\square$ all, $Q_{2}=$ all, and $Q_{3}=\diamond_{\text {some }}$, so the modal syllogism can be denoted as $\square \operatorname{all}(M, P) \wedge \operatorname{all}(S, M)$ $\Rightarrow \diamond$ some $(S, P)$. The other cases are similar.

To full appreciate this paper, one will need basic familiarity with the terminology of first-order logic, generalized quantifier theory, set theory and possible world semantics [26].

\section{Preliminaries}

The type $\langle 1\rangle$ and type $\langle 1,1\rangle$ quantifiers are ubiquitous in the natural languages. The former are properties of sets of things and the latter are binary relations between sets of things or stuff [27]. The four Aristotelian quantifiers are just four instances of type $\langle 1,1\rangle$ generalized quantifiers [21].

For example, a quantified sentence 'Some students are sleeping' is denoted by $\operatorname{some}(S, P)$, where $S$ is the set of students in a given domain, $P$ is the set of things that are sleeping in the domain, and the type $\langle 1,1\rangle$ quantifier some is a relation between sets which is a particularly simple relation to describe: $S \cap P \neq \varnothing$.

Let $S, P$ be arbitrary sets, the relations which Aristotelian quantifiers stand for can be given in standard set-theoretic notations as the following:

Definition 1:
(1) $\operatorname{all}(\mathrm{S}, \mathrm{P}) \Leftrightarrow \mathrm{S} \subseteq \mathrm{P}$;
(3) $\operatorname{some}(S, P) \Leftrightarrow S \cap P \neq \varnothing$;
(2) $\operatorname{no}(\mathrm{S}, \mathrm{P}) \Leftrightarrow \mathrm{S} \cap \mathrm{P}=\varnothing$;
(4) not all $(S, P) \Leftrightarrow S-P \neq \varnothing$.

(Please cut " $\varnothing ; "$ off)

For the sake of simplicity, the universal affirmative proposition 'All $S$ are $P$ ' is denoted by all $(S, P)$ and abbreviated by A proposition, the universal negative proposition ' $N o$ are $P$ ' is denoted by $n o(S, P)$ and abbreviated by $\mathrm{E}$ proposition, the particular affirmative proposition 'Some $S$ are $P$ ' is denoted by $\operatorname{some}(S, P)$ and abbreviated by I proposition, and the particular negative proposition 'Not all $S$ are $P$ ' is denoted by not all $(S, P)$ and abbreviated by $\mathrm{O}$ proposition. The proposition 'All $S$ are necessarily $P$ ' is denoted by $\square$ all $(S, P)$ and abbreviated by $\square$ A proposition. The proposition 'Some $S$ are possibly $P$ ' is denoted by $\diamond$ some $(S, P)$ and abbreviated by $\diamond \mathrm{I}$ proposition. The other cases are similar.

Let $p$ be any proposition, necessarily $p$ is denoted by $\square p$, and possibly $p$ is denoted by $\diamond p$. According to the modal logic [28-29], necessity is what is true at every possible world and possibility is what is true at some. More specifically, one has the following:

Definition 2:

(1) $\square p$ is true, if and only if $p$ itself is true at every possible world;

(2) $\diamond p$ is true, if and only if $p$ itself is true at least one possible world;

In term of Definition 1 and Definition 2, one has the following:

Definition 3:

(1) $\square \operatorname{all}(S, P)$ is true, if and only if $S \subseteq P$ is true at every possible world.

(2) $\diamond \operatorname{all}(S, P)$ is true, if and only if $S \subseteq P$ is true at least one possible world.

(3) $\square \operatorname{some}(S, P)$ is true, if and only if $S \cap P \neq \varnothing$ is true at every possible world.

(4) $\diamond$ some $(S, P)$ is true, if and only if $S \cap P \neq \varnothing$ is true at least one possible world.

(5) $\square$ no $(S, P)$ is true, if and only if $S \cap P=\varnothing$ is true at every possible world.

(6) $\diamond n o(S, P)$ is true, if and only if $S \cap P=\varnothing$ is true at least one possible world.

(7) $\square$ not $\operatorname{all}(S, P)$ is true, if and only if $S-P \neq \varnothing$ is true at every possible world.

$(8) \diamond$ not $\operatorname{all}(S, P)$ is true, if and only if $S-P \neq \varnothing$ is true at least one possible world.

In term of Definition 3 , it is clear that $\square p \Rightarrow p, p \Rightarrow \diamond p$, and $\square p \Rightarrow \diamond p$ in any model, in which $p$ is a proposition. More specifically, the following Fact 1 holds.

Fact 1:
(1) $\square \operatorname{all}(\mathrm{S}, \mathrm{P}) \Rightarrow \operatorname{all}(\mathrm{S}, \mathrm{P})$;
(3) $\square \mathrm{no}(\mathrm{S}, \mathrm{P}) \Rightarrow \mathrm{no}(\mathrm{S}, \mathrm{P})$;
(5) $\operatorname{all}(\mathrm{S}, \mathrm{P}) \Rightarrow \diamond \operatorname{all}(\mathrm{S}, \mathrm{P})$;
(7) $\mathrm{no}(\mathrm{S}, \mathrm{P}) \Rightarrow \diamond \mathrm{no}(\mathrm{S}, \mathrm{P})$;
(9) $\square \operatorname{all}(\mathrm{S}, \mathrm{P}) \Rightarrow \diamond \operatorname{all}(\mathrm{S}, \mathrm{P})$;
(11) $\square \mathrm{no}(\mathrm{S}, \mathrm{P}) \Rightarrow \diamond \mathrm{no}(\mathrm{S}, \mathrm{P})$;
(13) $\square$ all(S, P) $\Rightarrow \square$ some(S, P);
(15) $\square$ no(S, P) $\Rightarrow \square$ not all(S, P);
(17) all(S, P) $\Rightarrow$ some(S, P);

(2) $\square$ some(S, P) $\Rightarrow$ some(S, P);

(4) $\square$ not all(S, P) $\Rightarrow$ not all(S, P);

(6) some $(\mathrm{S}, \mathrm{P}) \Rightarrow \diamond$ some $(\mathrm{S}, \mathrm{P})$;

(8) not all(S, P) $\Rightarrow \diamond$ not all(S, P);

(10) $\square$ some $(\mathrm{S}, \mathrm{P}) \Rightarrow \diamond_{\text {some }}(\mathrm{S}, \mathrm{P})$;

(12) $\square$ not all(S, P) $\Rightarrow \diamond$ not all(S, P);

(14) $\diamond$ all $(\mathrm{S}, \mathrm{P}) \Rightarrow \diamond_{\mathrm{some}}(\mathrm{S}, \mathrm{P})$;

(16) $\diamond$ no(S, P) $\Rightarrow \diamond$ not all (S, P);

(18) no(S, P) $\Rightarrow \operatorname{not} \operatorname{all}(\mathrm{S}, \mathrm{P})$. 
Similar to classical syllogisms, modal syllogisms can be grouped into four different 'figures':

$\begin{array}{ll}\text { (1) first figure } & \text { (2) second figure } \\ Q_{1}(M, P) & Q_{1}(P, M) \\ Q_{2}(S, M) & Q_{2}(S, M) \\ Q_{3}(S, P) & Q_{3}(S, P)\end{array}$

Here $Q$ can be chosen among the following 12 generalized quantifiers all, some, no, not all, $\square$ all, $\square$ some, $\square$ no, $\square$ not all, $\diamond$ all, $\nabla_{\text {some, }} \nabla_{\text {no, }} \nabla_{\text {not }}$ all, so there are $12 \times 12 \times 12 \times 4$ $-4 \times 4 \times 4 \times 4=6656$ Aristotelian modal syllogisms. A modal syllogism is valid if each instantiation of $S, M$ and $P$ verifying the premises also verifies the conclusion. For what choices of quantifiers are the above figures valid? In the follows the paper tries to find out all valid Aristotelian modal syllogisms.

For instance, in the first figure, if suppose that $Q_{1}=Q_{2}=\square$ all and $Q_{3}=\diamond$ all and, then the syllogism $\square$ all $(M$, $P) \wedge \square \operatorname{all}(S, M) \Rightarrow \diamond \operatorname{some}(S, P)$ is valid. The syllogism can be abbreviated by $\square \mathrm{A} \square \mathrm{A} \diamond \mathrm{I}-1$. Similarly, the syllogism $\square \operatorname{all}(M, P) \wedge n o(M, S) \Rightarrow \diamond$ not all $(S, P)$ can be abbreviated by $\square \mathrm{AE} \diamond \mathrm{O}-3$. The other denotations are similar.

\section{The Formal Proof for Valid Aristotelian Modal Syllogisms}

On the basis of generalized quantifier theory, set theory, and possible world semantics [26], one can prove that which modal syllogisms are valid by means of Definition 3 and Fact 1. Proofs for some of the following syllogisms can be easily constructed and will be omitted.

Theorem 1 ( $\square \mathrm{A} \square \mathrm{A} \square \mathrm{A}-1$ ): $\square \operatorname{all}(M, P) \wedge \square \operatorname{all}(S, M) \Rightarrow$ $\square \operatorname{all}(S, P)$ is valid.

Example 1,

Major premise: All animals necessarily eat something.

Minor premise: All dogs are necessarily animals.

Conclusion: All dogs necessarily eat something.

Let $S$ is the set of dogs in a given domain, $P$ is the set of things that eat something in the domain, and $M$ is the set of animals in the domain. Example 1 of the modal syllogism scheme can be formalized by $\square \operatorname{all}(M, P) \wedge \square \operatorname{all}(S, M)$ $\Rightarrow \square \operatorname{all}(S, P)$, abbreviated by $\square \mathrm{A} \square \mathrm{A} \square \mathrm{A}-1$. The other cases are similar.

Proof: Suppose that $\square \operatorname{all}(M, P)$ and $\square$ all $(S, M)$ are true, then $M \subseteq P$ and $S \subseteq M$ is true at every possible world according to the clause (1) in Definition 3. Now it follows that $M \subseteq P$ and $S \subseteq M$, so one can easily derive that $S \subseteq P$ is true at every possible world. Hence $\square$ all $(S, P)$ is true in terms of the clause (1) in Definition 3 again. This proves the claim that the modal syllogism $\square \operatorname{all}(M, P) \wedge \square \operatorname{all}(S, M) \Rightarrow \square \operatorname{all}(S, P)$ is valid, just as desired.

Theorem 2: The following 5 modal syllogisms are valid:

(2.1) ( $\square \mathrm{A} \square \mathrm{A} \square \mathrm{I}-1): \square \operatorname{all}(M, P) \wedge \square \operatorname{all}(S, M) \Rightarrow \square \operatorname{all}(S$, P)

(2.2) ( $\square$ A $\square$ AA-1): $\square \operatorname{all}(M, P) \wedge \square \operatorname{all}(S, M) \Rightarrow \operatorname{all}(S, P)$

(2.3) ( $\square$ A $\square$ AI-1): $\square \operatorname{all}(M, P) \wedge \square \operatorname{all}(S, M) \Rightarrow \operatorname{some}(S, P)$

(2.4) ( $\square \mathrm{A} \square \mathrm{A} \diamond \mathrm{A}-1)$ : $\square \operatorname{all}(M, P) \wedge \square \operatorname{all}(S, M) \Rightarrow \diamond \operatorname{all}(S$,
(3) third figure

$Q_{1}(M, P)$

(4) fourth figure

$Q_{2}(M, S)$

$Q_{l}(P, M)$

$Q_{3}(S, P)$

$Q_{2}(M, S)$

$Q_{3}(S, P)$

P)

(2.5) ( $\square \mathrm{A} \square \mathrm{A} \diamond \mathrm{I}-1): \square \operatorname{all}(M, \quad P) \wedge \square \operatorname{all}(S, \quad M) \Rightarrow$ $\diamond$ some $(S, P)$

Theorem 2 can be easily derived from Theorem 1 and Fact 1.

Theorem 3 ( $\square$ AA $\square \mathrm{A}-1): \square \operatorname{all}(M, \quad P) \wedge \operatorname{all}(S, \quad M)$ $\Rightarrow \square \operatorname{all}(S, P)$ is valid.

Example 2,

Major premise: All animals necessarily die.

Minor premise: All birds are animals.

Conclusion: All birds necessarily die.

Proof: The validity of the modal syllogism can be similarly proved as Theorem 1. Suppose that $\square \operatorname{all}(M, P)$ and $\operatorname{all}(S, M)$ are true, then $\square \operatorname{all}(M, P)$ is true, if and only if $M \subseteq P$ is true at every possible world in terms of the clause (1) in Definition 3. Now it follows that $\operatorname{all}(S, M) \Leftrightarrow S \subseteq M$ by the clause (1) in Definition 1 . Thus it is easy to observe that $M \subseteq P$ and $S \subseteq M$ at every possible world, so $S \subseteq P$ is true at every possible world. Hence $\operatorname{all}(S, P)$ is true in term of the clause (1) in Definition 3 again. Therefore $\square \operatorname{all}(M, P) \wedge \operatorname{all}(S, M) \Rightarrow \square \operatorname{all}(S, P)$ is valid, as required.

Theorem 4: The following 4 modal syllogisms are valid:

(4.1) ( $\square$ AA $\square \mathrm{I}-1): \square \operatorname{all}(M, P) \wedge \operatorname{all}(S, M) \Rightarrow \square \operatorname{all}(S, P)$

(4.2) ( $\square \mathrm{AA} \diamond \mathrm{I}-1): \square \operatorname{all}(M, P) \wedge \operatorname{all}(S, M) \Rightarrow \diamond_{\text {some }}(S$, P)

(4.3) ( $\square$ AAA-1): $\square \operatorname{all}(M, P) \wedge \operatorname{all}(S, M) \Rightarrow \operatorname{all}(S, P)$

(4.4) ( $\square$ AAI-1): $\square \operatorname{all}(M, P) \wedge \operatorname{all}(S, M) \Rightarrow \operatorname{some}(S, P)$

Theorem 4 can be certainly deduced from Theorem 3 and Fact 1.

Theorem $5(\square \mathrm{A} \diamond \mathrm{A} \diamond \mathrm{A}-1): \square \operatorname{all}(M, P) \wedge \diamond \operatorname{all}(S, M)$ $\Rightarrow \diamond \operatorname{all}(S, P)$ is valid.

Proof: Suppose that $\square$ all $(M, P)$ and $\diamond$ all $(S, M)$ are true, then $\square \operatorname{all}(M, P)$ is true, if and only if $S \subseteq P$ is true at every possible world according to the clause (1) in Definition 3; then $\diamond$ all $(S, M)$ is true, if and only if $S \subseteq M$ is true at least possible world in term of the clause (2) in Definition 3. Now it shows that $M \subseteq P$ and $S \subseteq M$ are both true at least possible world, so $S \subseteq P$ is true at least possible world. Hence $\diamond$ all $(S$, $P)$ is true by the clause (2) in Definition 3 again. It follows that $\square \operatorname{all}(M, P) \wedge \diamond \operatorname{all}(S, M) \Rightarrow \diamond \operatorname{all}(S, P)$ is valid, just as desired.

Theorem 6 ( $\square \mathrm{A} \diamond \mathrm{A} \diamond \mathrm{I}-1): \square \operatorname{all}(M, P) \wedge \diamond \operatorname{all}(S, M)$ $\Rightarrow \diamond$ some $(S, P)$ is valid.

Theorem 6 can be deducible from Theorem 5 and the clause (14) in Fact 1.

Theorem $7(\mathrm{~A} \diamond \mathrm{A} \diamond \mathrm{A}-1): \operatorname{all}(M, \quad P) \wedge \diamond \operatorname{all}(S, M)$ $\Rightarrow \diamond$ some $(S, P)$ is valid.

Similar to Theorem 3, Theorem 7 can be proved by means of Definition 1 and Definition 3.

Theorem $8(\mathrm{~A} \diamond \mathrm{A} \diamond \mathrm{I}-1): \operatorname{all}(M, \quad P) \wedge \diamond \operatorname{all}(S, \quad M)$ $\Rightarrow \diamond$ some $(S, P)$ is valid.

Theorem 8 can be followed from Theorem 7 and the clause 
(14) in Fact 1.

A careful observation of the proven valid modal syllogisms will reveal that the classical syllogism obtained after removing all modal operators from a valid modal syllogism is also valid. For example, $\square \mathrm{EA} \square \mathrm{E}-1$ is valid, and EAE-1 obtained after removing all modal operators is also valid. In other words, a valid modal syllogism may be obtained by adding modal operators to a valid classical syllogism. Therefore, in addition to satisfying all the general rules of valid classical syllogisms, a valid modal syllogism must satisfy the characteristic rules of modal syllogisms [26]. That is, a valid modal syllogism must satisfy the following five rules:

Rule 1: The premises contains at least one universal proposition, that is, at least including one of the six propositions A, E, $\square \mathrm{A}, \square \mathrm{E}, \diamond \mathrm{A}$ and $\diamond \mathrm{E}$. Therefore, a modal syllogism only consisting of the six propositions I, O, $\square \mathrm{I}, \square \mathrm{O}, \diamond \mathrm{I}$ and $\diamond \mathrm{O}$ is invalid. There are $(6 \times 6 \times 6 \times 4=) 864$ invalid modal syllogisms composed of them. And there are $(2 \times 2 \times 2 \times 4=) 32$ invalid classical syllogisms only composed of $\mathrm{I}$ and $\mathrm{O}$ propositions, therefore the number of invalid modal syllogisms composed of the six propositions I, O, $\square$, $\square \mathrm{O}, \diamond \mathrm{I}$ and $\diamond \mathrm{O}$ is $(864-32=) 832$.

Rule 2: For a modal syllogism, the number of negative propositions in the two premises is the same in the conclusion. Hence the following three types of modal syllogisms are invalid: (a) two negative premises and one affirmative conclusion; (b) major and minor premises are affirmative and the conclusion are negative; (c) the two premises and the conclusion are negative. The affirmative propositions in a modal syllogism refer to A, I, $\square \mathrm{A}, \square \mathrm{I}, \diamond \mathrm{A}$ and $\diamond \mathrm{I}$, the negative propositions refer to $\mathrm{E}, \mathrm{O}, \square \mathrm{E}, \square \mathrm{O}$, $\diamond \mathrm{E}$ and $\diamond \mathrm{O}$. Therefore, the number of the three types of invalid modal syllogisms is $(6 \times 6 \times 6 \times 4-2 \times 2 \times 2 \times 4)+$ $(6 \times 6 \times 6 \times 4-2 \times 2 \times 2 \times 4)+(6 \times 6 \times 6 \times 4-2 \times 2 \times 2 \times 4)=2496$.

Rule 3: If one of the premises in a modal syllogism is a particular proposition, the conclusion must also be a particular. The following two types of modal syllogisms are invalid: (a) one particular premise, one universal premise, and one universal conclusion; (b) two particular premises, and one universal conclusion. The number of the two type of invalid modal syllogisms is $(6 \times 6 \times 6 \times 4-2 \times 2 \times 2 \times 4)+$ $(6 \times 6 \times 6 \times 4-2 \times 2 \times 2 \times 4)=1664$.

At this point, it can be seen that there are at most 6656-832-2496 -1664 = 1664 valid modal syllogisms. In fact, some of these 1664 modal syllogisms are invalid. Therefore, It is necessary to formulate new characteristic rules to eliminate invalid modal syllogisms.

Rule 4: As long as one of the two premises in a modal syllogism is a possible proposition, it is impossible to derive a necessary or an assertoric conclusion. Otherwise the modal syllogism is invalid. The following two types of modal syllogisms are invalid: (a) one possible premise, one necessary premise, and one necessary conclusion; (b) two possible premises, and one necessary conclusion. The number of this type of invalid modal syllogisms is $4 \times 4 \times 4 \times 4+$ $4 \times 4 \times 4 \times 4=512$.

Rule 5: As long as the two premises in a modal syllogism are assertoric propositions, it is impossible to derive a necessary conclusion. However, a necessary premise and an assertoric premise in a modal syllogism may lead to a necessary conclusion. The number of this type of invalid modal syllogisms is $4 \times 12 \times 4 \times 4=768$.

According to Rule 1 and Rule 3, To sum up, the number of valid Aristotelian modal syllogisms is $1664-512-768=384$.

A modal syllogism is valid only if it satisfies all the above five rules. If any of the rules is violated, it is invalid. Among them, the first three rules are also the rules that a valid classical syllogism must be satisfied. Therefore, adding modal operators to a classical syllogism to seek out a valid modal syllogism only needs to check whether or not Rule 4 and Rule 5 are satisfied. if satisfied, the modal syllogism is valid, otherwise it is invalid. This treatment will greatly increase our efficiency in screening out all Aristotelian valid modal syllogisms. Which modal syllogisms are valid? The following section answers the question.

\section{Method of Screening out all Valid Aristotelian Modal Syllogisms}

Now the following paper illustrates how to get all possible Aristotelian modal syllogisms obtained by adding modal operators to 24 valid classical syllogisms, and how to eliminate invalid modal syllogisms by Rule 4 and Rule 5 [26]. That is, it shows how to screen out all Aristotelian valid modal syllogisms from 6656 Aristotelian modal syllogisms in natural language.

One can firstly examine the first figure modal syllogisms obtained by adding modal operators to one of the first figure valid classical syllogisms AAA-1, AAI-1, AII-1, EAE-1 and EAO-1. There are three possibilities for the number of modal operators in the modal syllogisms: (1) just one modal operator; (2) two modal operators; (3) three modal operators.

\subsection{Valid Modal Syllogisms Obtained by Adding Modal Operators to a Valid Classical Syllogism}

Here is an example to illustrate the process of obtaining valid Aristotelian modal syllogisms. Valid modal syllogisms can be obtained by adding modal operators to the valid classical syllogism AAA-1.

(1) There are 8 modal syllogisms containing three modal operators by adding modal operators to the classical syllogism AAA-1, that is, [001] $\square \mathrm{A} \square \mathrm{A} \square \mathrm{A}-1$, [002] $\diamond \mathrm{A} \diamond \mathrm{A} \diamond \mathrm{A}-1$, [003] $\square \mathrm{A} \square \mathrm{A} \diamond \mathrm{A}-1$, [004] $\square \mathrm{A} \diamond \mathrm{A} \square \mathrm{A}-1$, [005] $\diamond \mathrm{A} \square \mathrm{A} \square \mathrm{A}-1, \quad[006] \quad \square \mathrm{A} \diamond \mathrm{A} \diamond \mathrm{A}-1, \quad$ [007] $\diamond \mathrm{A} \square \mathrm{A} \diamond \mathrm{A}-1$ and [008] $\diamond \mathrm{A} \diamond \mathrm{A} \square \mathrm{A}-1$. But one of the premises in [004] $\square \mathrm{A} \diamond \mathrm{A} \square \mathrm{A}-1$, [005] $\diamond \mathrm{A} \square \mathrm{A} \square \mathrm{A}-1$ and [008] $\diamond \mathrm{A} \diamond \mathrm{A} \square \mathrm{A}-1$ is a possible proposition, and the conclusion is a necessary proposition. The three modal syllogisms violate Rule 4 and are invalid. The other five modal syllogisms are valid.

(2) There are 8 modal syllogisms containing two modal operators by adding modal operators to the classical syllogism AAA-1, that is, [009] $\square$ A $\square$ AA-1, [010] 
$\square \mathrm{AA} \square \mathrm{A}-1$, [011] $\mathrm{A} \square \mathrm{A} \square \mathrm{A}-1$, [012] $\diamond \mathrm{A} \diamond \mathrm{AA}-1$, [013] $\diamond \mathrm{AA} \diamond \mathrm{A}-1,[014] \mathrm{A} \diamond \mathrm{A} \diamond \mathrm{A}-1,[015] \quad \square \mathrm{A} \diamond \mathrm{AA}-1,[016]$ $\square \mathrm{AA} \diamond \mathrm{A}-1$, [017] $\mathrm{A} \square \mathrm{A} \diamond \mathrm{A}-1$, [018] $\diamond \mathrm{A} \square \mathrm{AA}-1$, [019] $\diamond \mathrm{AA} \square \mathrm{A}-1$, and [020] $\mathrm{A} \diamond \mathrm{A} \square \mathrm{A}-1$. But one of the premises in [012] $\diamond \mathrm{A} \diamond \mathrm{AA}-1,[018] \diamond \mathrm{A} \square \mathrm{AA}-1,[019] \diamond \mathrm{AA} \square \mathrm{A}-1$ and [020] $\mathrm{A} \diamond \mathrm{A} \square \mathrm{A}-1$ is a possible proposition, and the conclusion is a necessary or an assertoric proposition. The four modal syllogisms also violate Rule 4 and are invalid. The other eight modal syllogisms are valid.

(3) There are 5 modal syllogisms containing one modal operator by adding modal operators to the classical syllogism AAA-1, that is, [021] $\square$ AAA-1, [022] A $\square$ AA-1, [023] $\mathrm{AA} \square \mathrm{A}-1$, [024] $\diamond \mathrm{AAA}-1$, [025] A $\diamond \mathrm{AA}-1$ and [026] AA $\diamond \mathrm{A}-1$. But [023] AA $\square$ A-1 has two assertoric propositions, implies a necessary proposition, and is invalid in violation of Rule 5. And one of the premises in [024] $\diamond$ AAA-1 and [025] A $\diamond$ AA-1 is a possible proposition, and the conclusion is an assertoric proposition. The two modal syllogisms also violate Rule 4 and are invalid. Therefore, only the three modal syllogisms [021], [022] and [026] are valid here.

It can be seen from (1), (2) and (3) that there are $(5+8+3=)$ 16 valid modal syllogisms obtained by adding modal operators to classical syllogism AAA-1.

\subsection{Total Valid Modal Syllogisms}

Similar to 4.1 just illustrated, there are exactly 16 valid modal syllogisms obtained by adding modal operators to any other valid classical syllogism, such as AAI-1, AEO-2, EIO-3, and AEE-4. This is because in any two different valid classical syllogisms, all the possible cases of the number of operators added and the order of addition are the same. Therefore, the number of modal syllogisms obtained by adding modal operators is the same, and the number of valid modal syllogisms is the same and the number of invalid modal syllogisms is the same. Therefore, there are $(24 \times 16=) 384$ valid Aristotelian modal syllogisms obtained by adding modal operators to 24 valid classical syllogisms [26]. That is to say, in 6656 Aristotelian modal syllogisms, the total number of valid modal syllogisms is 384 , just as the result calculated earlier, and the total number of invalid modal syllogisms is (6656-384=) 6272 .

The following 384 Aristotelian modal syllogisms from Theorem 9-Theorems 32 are valid:

Theorem 9: The following modal syllogisms obtained by adding modal operators to the valid classical syllogism AAA-1 are valid:

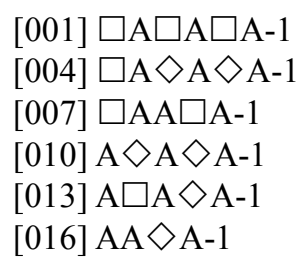

$[002] \diamond \mathrm{A} \diamond \mathrm{A} \diamond \mathrm{A}-1$
$[005] \diamond \mathrm{A} \square \mathrm{A} \diamond \mathrm{A}-1$
$[008] \mathrm{A} \square \mathrm{A} \square \mathrm{A}-1$
$[011] \square \mathrm{A} \diamond \mathrm{AA}-1$
$[014] \square \mathrm{AAA}-1$

Theorem 10: The following modal syllogisms obtained by adding modal operators to the valid classical syllogism AAI-1 are valid:
$[003] \square \mathrm{A} \square \mathrm{A} \diamond \mathrm{A}-1$
$[006] \square \mathrm{A} \square \mathrm{AA}-1$
$[009] \diamond \mathrm{AA} \diamond \mathrm{A}-1$
$[012] \square \mathrm{AA} \diamond \mathrm{A}-1$
$[015] \mathrm{A} \square \mathrm{AA}-1$

$[018] \diamond \mathrm{A} \diamond \mathrm{A} \diamond \mathrm{I}-1$
$[21] \diamond \mathrm{A} \square \mathrm{A} \diamond \mathrm{I}-1$
$[024] \mathrm{A} \square \mathrm{A} \square \mathrm{I}-1$
$[027] \square \mathrm{A} \diamond \mathrm{AI}-1$
$[030] \square \mathrm{AAI}-1$

$[019] \square \mathrm{A} \square \mathrm{A} \diamond \mathrm{I}-1$
$[022] \square \mathrm{A} \square \mathrm{AI}-1$
$[025] \diamond \mathrm{AA} \diamond \mathrm{I}-1$
$[028] \square \mathrm{AA} \diamond \mathrm{I}-1$
$[031] \mathrm{A} \square \mathrm{AI}-1$

[019] $\square \mathrm{A} \square \mathrm{A} \diamond \mathrm{I}-1$

[022] $\square \mathrm{A} \square \mathrm{AI}-1$

$[028] \square \mathrm{AA} \diamond \mathrm{I}-1$

[031] A $\square \mathrm{AI}-1$

Theorem 11: The following modal syllogisms obtained by adding modal operators to the valid classical syllogism AII-1 are valid:

$$
\begin{aligned}
& {[033] \square \mathrm{A} \square \mathrm{I} \square \mathrm{I}-1} \\
& {[036] \square \mathrm{A} \diamond \mathrm{I} \diamond \mathrm{I}-1} \\
& {[039] \square \mathrm{AI} \square \mathrm{I}-1} \\
& {[042] \mathrm{A} \diamond \mathrm{I} \diamond \mathrm{I}-1} \\
& {[045] \mathrm{A} \square \mathrm{I} \diamond \mathrm{I}-1} \\
& {[048] \mathrm{AI} \diamond \mathrm{I}-1}
\end{aligned}
$$

$[034] \diamond \mathrm{A} \diamond \mathrm{I} \diamond \mathrm{I}-1$
$[037] \diamond \mathrm{A} \square \mathrm{I} \diamond \mathrm{I}-1$
$[040] \mathrm{A} \square \mathrm{I} \square \mathrm{I}-1$
$[043] \square \mathrm{A} \diamond \mathrm{II}-1$
$[046] \square \mathrm{AII}-1$

\author{
[035] $\square \mathrm{A} \square \mathrm{I} \diamond \mathrm{I}-1$ \\ [038] $\square \mathrm{A} \square \mathrm{II}-1$ \\ $[041] \diamond \mathrm{AI} \diamond \mathrm{I}-1$ \\ $[044] \square \mathrm{AI} \diamond \mathrm{I}-1$ \\ [047] A $\square$ II-1
}

Theorem 12: The following modal syllogisms obtained by adding modal operators to the valid classical syllogism EAE-1 are valid:
[049] $\square \mathrm{E} \square \mathrm{A} \square \mathrm{E}-1$
$[052] \square \mathrm{E} \diamond \mathrm{A} \diamond \mathrm{E}-1$
[055] $\square \mathrm{EA} \square \mathrm{E}-1$
[058] $\mathrm{E} \diamond \mathrm{A} \diamond \mathrm{E}-1$

$[050] \diamond \mathrm{E} \diamond \mathrm{A} \diamond \mathrm{E}-1$
$[053] \diamond \mathrm{E} \square \mathrm{A} \diamond \mathrm{E}-1$
$[056] \mathrm{E} \square \mathrm{A} \square \mathrm{E}-1$
$[059] \square \mathrm{E} \diamond \mathrm{AE}-1$

$[051] \square \mathrm{E} \square \mathrm{A} \diamond \mathrm{E}-1$
$[054] \square \mathrm{E} \square \mathrm{AE}-1$
$[057] \diamond \mathrm{EA} \diamond \mathrm{E}-1$
$[060] \square \mathrm{EA} \diamond \mathrm{E}-1$ 

[061] $\mathrm{E} \square \mathrm{A} \diamond \mathrm{E}-1$
[062] $\square$ EAE-1
[063] E $\square \mathrm{AE}-1$
[064] EA $\diamond \mathrm{E}-1$

Theorem 13: The following modal syllogisms obtained by adding modal operators to the valid classical syllogism EAO-1 are valid:

$\begin{array}{lll}{[065] \square \mathrm{E} \square \mathrm{A} \square \mathrm{O}-1} & {[066] \diamond \mathrm{E} \diamond \mathrm{A} \diamond \mathrm{O}-1} & {[067] \square \mathrm{E} \square \mathrm{A} \diamond \mathrm{O}-1} \\ {[068] \square \mathrm{E} \diamond \mathrm{A} \diamond \mathrm{O}-1} & {[069] \diamond \mathrm{E} \square \mathrm{A} \diamond \mathrm{O}-1} & {[070] \square \mathrm{E} \square \mathrm{AO}-1} \\ {[071] \square \mathrm{EA} \square \mathrm{O}-1} & {[072] \mathrm{E} \square \mathrm{A} \square \mathrm{O}-1} & {[073] \diamond \mathrm{EA} \diamond \mathrm{O}-1} \\ {[074] \mathrm{E} \diamond \mathrm{A} \diamond \mathrm{O}-1} & {[075] \square \mathrm{E} \diamond \mathrm{AO}-1} & {[076] \square \mathrm{EA} \diamond \mathrm{O}-1} \\ {[077] \mathrm{E} \square \mathrm{A} \diamond \mathrm{O}-1} & {[078] \square \mathrm{EAO}-1} & {[079] \mathrm{E} \square \mathrm{AO}-1} \\ {[080] \mathrm{EA} \diamond \mathrm{O}-1} & \end{array}$

Theorem 14: The following modal syllogisms obtained by adding modal operators to the valid classical syllogism EIO-1 are valid:

$\begin{array}{lll}{[081] \square \mathrm{E} \square \mathrm{I} \square \mathrm{O}-1} & {[082] \diamond \mathrm{E} \diamond \mathrm{I} \diamond \mathrm{O}-1} & {[083] \square \mathrm{E} \square \mathrm{I} \diamond \mathrm{O}-1} \\ {[084] \square \mathrm{E} \diamond \mathrm{I} \diamond \mathrm{O}-1} & {[085] \diamond \mathrm{E} \square \mathrm{I} \diamond \mathrm{O}-1} & {[086] \square \mathrm{E} \square \mathrm{IO}-1} \\ {[087] \square \mathrm{EI} \square \mathrm{O}-1} & {[088] \mathrm{E} \square \mathrm{I} \square \mathrm{O}-1} & {[089] \diamond \mathrm{EI} \diamond \mathrm{O}-1} \\ {[090] \mathrm{E} \diamond \mathrm{I} \diamond \mathrm{O}-1} & {[091] \square \mathrm{E} \diamond \mathrm{IO}-1} & {[092] \square \mathrm{EI} \diamond \mathrm{O}-1} \\ {[093] \mathrm{E} \square \mathrm{I} \diamond \mathrm{O}-1} & {[094] \square \mathrm{EIO}-1} & {[095] \mathrm{E} \square \mathrm{IO}-1}\end{array}$

[096] EI $\diamond \mathrm{O}-1$

Theorem 15: The following modal syllogisms obtained by adding modal operators to the valid classical syllogism AEE-2 are valid:

$\begin{array}{lll}{[097] \square \mathrm{A} \square \mathrm{E} \square \mathrm{E}-2} & {[098] \diamond \mathrm{A} \diamond \mathrm{E} \diamond \mathrm{E}-2} & {[099] \square \mathrm{A} \square \mathrm{E} \diamond \mathrm{E}-2} \\ {[100] \square \mathrm{A} \diamond \mathrm{E} \diamond \mathrm{E}-2} & {[101] \diamond \mathrm{A} \square \mathrm{E} \diamond \mathrm{E}-2} & {[102] \square \mathrm{A} \square \mathrm{EE}-2} \\ {[103] \square \mathrm{AE} \square \mathrm{E}-2} & {[104] \mathrm{A} \square \mathrm{E} \square \mathrm{E}-2} & {[105] \diamond \mathrm{AE} \diamond \mathrm{E}-2} \\ {[106] \mathrm{A} \diamond \mathrm{E} \diamond \mathrm{E}-2} & {[107] \square \mathrm{A} \diamond \mathrm{EE}-2} & {[108] \square \mathrm{AE} \diamond \mathrm{E}-2} \\ {[109] \mathrm{A} \square \mathrm{E} \diamond \mathrm{E}-2} & {[110] \square \mathrm{AEE}-2} & {[111] \mathrm{A} \square \mathrm{EE}-2}\end{array}$

[112] AE $\diamond \mathrm{E}-2$

Theorem 16: The following modal syllogisms obtained by adding modal operators to the valid classical syllogism AEO-2 are valid:

$\begin{array}{lll}{[113] \square \mathrm{A} \square \mathrm{E} \square \mathrm{O}-2} & {[114] \diamond \mathrm{A} \diamond \mathrm{E} \diamond \mathrm{O}-2} & {[115] \square \mathrm{A} \square \mathrm{E} \diamond \mathrm{O}-2} \\ {[116] \square \mathrm{A} \diamond \mathrm{E} \diamond \mathrm{O}-2} & {[117] \diamond \mathrm{A} \square \mathrm{E} \diamond \mathrm{O}-2} & {[118] \square \mathrm{A} \square \mathrm{EO}-2} \\ {[119] \square \mathrm{AE} \square \mathrm{O}-2} & {[120] \mathrm{A} \square \mathrm{E} \square \mathrm{O}-2} & {[121] \diamond \mathrm{AE} \diamond \mathrm{O}-2} \\ {[122] \mathrm{A} \diamond \mathrm{E} \diamond \mathrm{O}-2} & {[123] \square \mathrm{A} \diamond \mathrm{EO}-2} & {[124] \square \mathrm{AE} \diamond \mathrm{O}-2} \\ {[125] \mathrm{A} \square \mathrm{E} \diamond \mathrm{O}-2} & {[126] \square \mathrm{AEO}-2} & {[127] \mathrm{A} \square \mathrm{EO}-2}\end{array}$

[128] AE $\diamond \mathrm{O}-2$

Theorem 17: The following modal syllogisms obtained by adding modal operators to the valid classical syllogism EAE-2 are valid:
[129] $\square \mathrm{E} \square \mathrm{A} \square \mathrm{E}-2$
[132] $\square \mathrm{E} \diamond \mathrm{A} \diamond \mathrm{E}-2$
$[130] \diamond \mathrm{E} \diamond \mathrm{A} \diamond \mathrm{E}-2$
$[133] \diamond \mathrm{E} \square \mathrm{A} \diamond \mathrm{E}-2$
[136] E $\square \mathrm{A} \square \mathrm{E}-2$
[135] $\square \mathrm{EA} \square \mathrm{E}-2$
[139] $\square \mathrm{E} \diamond \mathrm{AE}-2$
[138] $\mathrm{E} \diamond \mathrm{A} \diamond \mathrm{E}-2$
[142] $\square$ EAE-2
[131] $\square \mathrm{E} \square \mathrm{A} \diamond \mathrm{E}-2$
[134] $\square \mathrm{E} \square \mathrm{AE}-2$
[137] $\diamond \mathrm{EA} \diamond \mathrm{E}-2$
$[140] \square \mathrm{EA} \diamond \mathrm{E}-2$
[143] E $\square$ AE-2
[144] EA $\diamond \mathrm{E}-2$

Theorem 18: The following modal syllogisms obtained by adding modal operators to the valid classical syllogism EAO-2 are valid:
[145] $\square \mathrm{E} \square \mathrm{A} \square \mathrm{O}-2$
$[148] \square \mathrm{E} \diamond \mathrm{A} \diamond \mathrm{O}-2$
[151] $\square \mathrm{EA} \square \mathrm{O}-2$
$[154] \mathrm{E} \diamond \mathrm{A} \diamond \mathrm{O}-2$
[157] E $\square \mathrm{A} \diamond \mathrm{O}-2$
[160] EA $\diamond \mathrm{O}-2$

[146] $\diamond \mathrm{E} \diamond \mathrm{A} \diamond \mathrm{O}-2$

[149] $\diamond \mathrm{E} \square \mathrm{A} \diamond \mathrm{O}-2$

[152] E $\square \mathrm{A} \square \mathrm{O}-2$

[155] $\square \mathrm{E} \diamond \mathrm{AO}-2$

[158] $\square$ EAO-2
[147] $\square \mathrm{E} \square \mathrm{A} \diamond \mathrm{O}-2$
[150] $\square \mathrm{E} \square \mathrm{AO}-2$
$[153] \diamond \mathrm{EA} \diamond \mathrm{O}-2$
[156] $\square \mathrm{EA} \diamond \mathrm{O}-2$
[159] E $\square$ AO-2

Theorem 19: The following modal syllogisms obtained by adding modal operators to the valid classical syllogism EIO-2 are valid: 


$[161] \square \mathrm{E} \square \mathrm{I} \square \mathrm{O}-2$
$[164] \square \mathrm{E} \diamond \mathrm{I} \diamond \mathrm{O}-2$
$[167] \square \mathrm{EI} \square \mathrm{O}-2$
$[170] \mathrm{E} \diamond \mathrm{I} \diamond \mathrm{O}-2$
$[173] \mathrm{E} \square \mathrm{I} \diamond \mathrm{O}-2$
$[176] \mathrm{EI} \diamond \mathrm{O}-2$

$\mathrm{EI} \diamond \mathrm{O}-2$

Theorem 20: The following modal syllogisms obtained by adding modal operators to the valid classical syllogism AOO-2 are valid:

$[177] \square \mathrm{A} \square \mathrm{O} \square \mathrm{O}-2$
$[180] \square \mathrm{A} \diamond \mathrm{O} \diamond \mathrm{O}-2$
$[183] \square \mathrm{AO} \square \mathrm{O}-2$
$[186] \mathrm{A} \diamond \mathrm{O} \diamond \mathrm{O}-2$
$[189] \mathrm{A} \square \mathrm{O} \diamond \mathrm{O}-2$
$[192] \mathrm{AO} \diamond \mathrm{O}-2$

$[163] \square \mathrm{E} \square \mathrm{I} \diamond \mathrm{O}-2$

$[162] \diamond \mathrm{E} \diamond \mathrm{I} \diamond \mathrm{O}-2$

$[168] \mathrm{E} \square \mathrm{I} \square \mathrm{O}-2$

$[171] \square \mathrm{E} \diamond \mathrm{IO}-2$

[174] $\square$ EIO-2
$[172] \square \mathrm{EI} \diamond \mathrm{O}-2$
$[169] \diamond \mathrm{EI} \diamond \mathrm{O}-2$

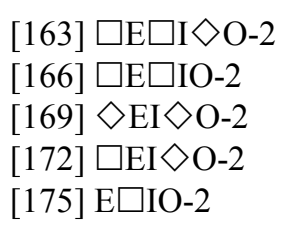

$[175] \mathrm{E} \square \mathrm{IO}-2$

[179] $\square \mathrm{A} \square \mathrm{O} \diamond \mathrm{O}-2$

$[182] \square \mathrm{A} \square \mathrm{OO}-2$

$[185] \diamond \mathrm{AO} \diamond \mathrm{O}-2$

$[188] \square \mathrm{AO} \diamond \mathrm{O}-2$

Theorem 21: The following modal syllogisms obtained by adding modal operators to the valid classical syllogism AII-3 are valid:
$[193] \square \mathrm{A} \square \mathrm{I} \square \mathrm{I}-3$
$[194] \diamond \mathrm{A} \diamond \mathrm{I} \diamond \mathrm{I}-3$
$[197] \diamond \mathrm{A} \square \mathrm{I} \diamond \mathrm{I}-3$
[200] A $\square \mathrm{I} \square \mathrm{I}-3$
[199] $\square \mathrm{AI} \square \mathrm{I}-3$
[203] $\square \mathrm{A} \diamond \mathrm{II}-3$
[202] $\mathrm{A} \diamond \mathrm{I} \diamond \mathrm{I}-3$
[206] $\square$ AII-3
$[195] \square \mathrm{A} \square \mathrm{I} \diamond \mathrm{I}-3$
$[198] \square \mathrm{A} \square \mathrm{II}-3$
$[201] \diamond \mathrm{AI} \diamond \mathrm{I}-3$
$[204] \square \mathrm{AI} \diamond \mathrm{I}-3$
[207] A $\square \mathrm{II}-3$
[205] $\mathrm{A} \square \mathrm{I} \diamond \mathrm{I}-3$

[208] AI $\diamond \mathrm{I}-3$

Theorem 22: The following modal syllogisms obtained by adding modal operators to the valid classical syllogism AAI-3 are valid:
[209] $\square \mathrm{A} \square \mathrm{A} \square \mathrm{I}-3$
[210] $\diamond \mathrm{A} \diamond \mathrm{A} \diamond \mathrm{I}-3$
[212] $\square \mathrm{A} \diamond \mathrm{A} \diamond \mathrm{I}-3$
[213] $\diamond \mathrm{A} \square \mathrm{A} \diamond \mathrm{I}-3$
[211] $\square \mathrm{A} \square \mathrm{A} \diamond \mathrm{I}-3$
[215] $\square \mathrm{AA} \square \mathrm{I}-3$
[216] A $\square \mathrm{A} \square \mathrm{I}-3$
[214] $\square \mathrm{A} \square \mathrm{AI}-3$
[218] A $\diamond \mathrm{A} \diamond \mathrm{I}-3$
[219] $\square \mathrm{A} \diamond \mathrm{AI}-3$
[217] $\diamond \mathrm{AA} \diamond \mathrm{I}-3$
[221] A $\square \mathrm{A} \diamond \mathrm{I}-3$
[222] $\square$ AAI-3
[220] $\square \mathrm{AA} \diamond \mathrm{I}-3$
[223] A $\square \mathrm{AI}-3$
[224] AA $\diamond \mathrm{I}-3$

Theorem 23: The following modal syllogisms obtained by adding modal operators to the valid classical syllogism EAO-3 are valid:
[225] $\square \mathrm{E} \square \mathrm{A} \square \mathrm{O}-3$
[226] $\diamond \mathrm{E} \diamond \mathrm{A} \diamond \mathrm{O}-3$
$[229] \diamond \mathrm{E} \square \mathrm{A} \diamond \mathrm{O}-3$
[227] $\square \mathrm{E} \square \mathrm{A} \diamond \mathrm{O}-3$
$[228] \square \mathrm{E} \diamond \mathrm{A} \diamond \mathrm{O}-3$
[232] $\mathrm{E} \square \mathrm{A} \square \mathrm{O}-3$
[230] $\square \mathrm{E} \square \mathrm{AO}-3$
[231] $\square$ EA $\square$ O-3
[235] $\square \mathrm{E} \diamond \mathrm{AO}-3$
[233] $\diamond \mathrm{EA} \diamond \mathrm{O}-3$
[234] E $\diamond \mathrm{A} \diamond \mathrm{O}-3$
[238] $\square$ EAO-3
[236] $\square \mathrm{EA} \diamond \mathrm{O}-3$
[239] E $\square$ AO-3
[240] EA $\diamond$ O-3

Theorem 24: The following modal syllogisms obtained by adding modal operators to the valid classical syllogism EIO-3 are valid:
[241] $\square \mathrm{E} \square \mathrm{I} \square \mathrm{O}-3$
[244] $\square \mathrm{E} \diamond \mathrm{I} \diamond \mathrm{O}-3$
[247] $\square \mathrm{EI} \square \mathrm{O}-3$
$[250] \mathrm{E} \diamond \mathrm{I} \diamond \mathrm{O}-3$
[253] E $\square \mathrm{I} \diamond \mathrm{O}-3$
[256] EI $\diamond \mathrm{O}-3$

[242] $\diamond \mathrm{E} \diamond \mathrm{I} \diamond \mathrm{O}-3$

$[245] \diamond \mathrm{E} \square \mathrm{I} \diamond \mathrm{O}-3$

[248] E $\square \mathrm{I} \square \mathrm{O}-3$

[251] $\square \mathrm{E} \diamond \mathrm{IO}-3$

[254] $\square$ EIO-3
[243] $\square \mathrm{E} \square \mathrm{I} \diamond \mathrm{O}-3$
[246] $\square \mathrm{E} \square \mathrm{IO}-3$
[249] $\diamond \mathrm{EI} \diamond \mathrm{O}-3$
[252] $\square \mathrm{EI} \diamond \mathrm{O}-3$
[255] E $\square$ IO-3、

Theorem 25: The following modal syllogisms obtained by adding modal operators to the valid classical syllogism IAI-3 are valid:

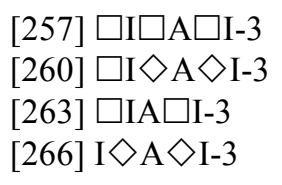

[257] $\square \mathrm{I} \square \mathrm{A} \square \mathrm{I}-3$

[260] $\square \mathrm{I} \diamond \mathrm{A} \diamond \mathrm{I}-3$

$[266] \mathrm{I} \diamond \mathrm{A} \diamond \mathrm{I}-3$
$[258] \diamond \mathrm{I} \diamond \mathrm{A} \diamond \mathrm{I}-3$
[261] $\diamond \mathrm{I} \square \mathrm{A} \diamond \mathrm{I}-3$
[264] I $\square$ A $\square$ I-3
[267] $\square \mathrm{I} \diamond \mathrm{AI}-3$

$[259] \square \mathrm{I} \square \mathrm{A} \diamond \mathrm{I}-3$
$[262] \square \mathrm{I} \square \mathrm{AI}-3$
$[265] \diamond \mathrm{IA} \diamond \mathrm{I}-3$
$[268] \square \mathrm{IA} \diamond \mathrm{I}-3$ 
[269] I $\square \mathrm{A} \diamond \mathrm{I}-3$

[270] $\square$ IAI-3

[271] I $\square$ AI-3

[272] IA $\diamond \mathrm{I}-3$

Theorem 26: The following modal syllogisms obtained by adding modal operators to the valid classical syllogism OAO-3 are valid:

$[273] \square \mathrm{O} \square \mathrm{A} \square \mathrm{O}-3$
$[276] \square \mathrm{O} \diamond \mathrm{A} \diamond \mathrm{O}-3$
$[279] \square \mathrm{OA} \square \mathrm{O}-3$
$[282] \mathrm{O} \diamond \mathrm{A} \diamond \mathrm{O}-3$
$[285] \mathrm{O} \square \mathrm{A} \diamond \mathrm{O}-3$
$[288] \mathrm{OA} \diamond \mathrm{O}-3$

Theorem 27: The following modal syllogisms obtained by adding modal operators to the valid classical syllogism AAI-4 are valid:

$[274] \diamond \mathrm{O} \diamond \mathrm{A} \diamond \mathrm{O}-3$
$[277] \diamond \mathrm{O} \square \mathrm{A} \diamond \mathrm{O}-3$
$[280] \mathrm{O} \square \mathrm{A} \square \mathrm{O}-3$
$[283] \square \mathrm{O} \diamond \mathrm{AO}-3$
$[286] \square \mathrm{OAO}-3$

[274] $\diamond \mathrm{O} \diamond \mathrm{A} \diamond \mathrm{O}-3$

[280] O $\square \mathrm{A} \square \mathrm{O}-3$

$[283] \square \mathrm{O} \diamond \mathrm{AO}-3$

$[286] \square$ OAO-3
$[275] \square \mathrm{O} \square \mathrm{A} \diamond \mathrm{O}-3$
$[278] \square \mathrm{O} \square \mathrm{AO}-3$
$[281] \diamond \mathrm{OA} \diamond \mathrm{O}-3$
$[284] \square \mathrm{OA} \diamond \mathrm{O}-3$
$[287] \mathrm{O} \square \mathrm{AO}-3$

\section{[289] $\square \mathrm{A} \square \mathrm{A} \square \mathrm{I}-4$ \\ [292] $\square \mathrm{A} \diamond \mathrm{A} \diamond \mathrm{I}-4$ \\ [295] $\square \mathrm{AA} \square \mathrm{I}-4$ \\ [298] $\mathrm{A} \diamond \mathrm{A} \diamond \mathrm{I}-4$ \\ [301] $\mathrm{A} \square \mathrm{A} \diamond \mathrm{I}-4$ \\ [304] AA $\diamond \mathrm{I}-4$}
[290] $\diamond \mathrm{A} \diamond \mathrm{A} \diamond \mathrm{I}-4$
[293] $\diamond \mathrm{A} \square \mathrm{A} \diamond \mathrm{I}-4$
[296] $\mathrm{A} \square \mathrm{A} \square \mathrm{I}-4$
[299] $\square \mathrm{A} \diamond \mathrm{AI}-4$
[302] $\square$ AAI-4

$[291] \square \mathrm{A} \square \mathrm{A} \diamond \mathrm{I}-4$
$[294] \square \mathrm{A} \square \mathrm{AI}-4$
$[297] \diamond \mathrm{AA} \diamond \mathrm{I}-4$
$[300] \square \mathrm{AA} \diamond \mathrm{I}-4$
$[303] \mathrm{A} \square \mathrm{AI}-4$

Theorem 28: The following modal syllogisms obtained by adding modal operators to the valid classical syllogism AEE-4 are valid:

$[305] \square \mathrm{A} \square \mathrm{E} \square \mathrm{E}-4$
$[308] \square \mathrm{A} \diamond \mathrm{E} \diamond \mathrm{E}-4$
$[311] \square \mathrm{AE} \square \mathrm{E}-4$
$[314] \mathrm{A} \diamond \mathrm{E} \diamond \mathrm{E}-4$
$[317] \mathrm{A} \square \mathrm{E} \diamond \mathrm{E}-4$
$[320] \mathrm{AE} \diamond \mathrm{E}-4$
$[306] \diamond \mathrm{A} \diamond \mathrm{E} \diamond \mathrm{E}-4$
$[309] \diamond \mathrm{A} \square \mathrm{E} \diamond \mathrm{E}-4$
[312] $\mathrm{A} \square \mathrm{E} \square \mathrm{E}-4$
$[315] \square \mathrm{A} \diamond \mathrm{EE}-4$
[318] $\square$ AEE-4

$[307] \square \mathrm{A} \square \mathrm{E} \diamond \mathrm{E}-4$
$[310] \square \mathrm{A} \square \mathrm{EE}-4$
$[313] \diamond \mathrm{AE} \diamond \mathrm{E}-4$
$[316] \square \mathrm{AE} \diamond \mathrm{E}-4$
$[319] \mathrm{A} \square \mathrm{EE}-4$

Theorem 29: The following modal syllogisms obtained by adding modal operators to the valid classical syllogism AEO-4 are valid:

$[321] \square \mathrm{A} \square \mathrm{E} \square \mathrm{O}-4$
$[324] \square \mathrm{A} \diamond \mathrm{E} \diamond \mathrm{O}-4$
$[327] \square \mathrm{AE} \square \mathrm{O}-4$
$[330] \mathrm{A} \diamond \mathrm{E} \diamond \mathrm{O}-4$
$[333] \mathrm{A} \square \mathrm{E} \diamond \mathrm{O}-4$
$[336] \mathrm{AE} \diamond \mathrm{O}-4$
$[322] \diamond \mathrm{A} \diamond \mathrm{E} \diamond \mathrm{O}-4$
$[325] \diamond \mathrm{A} \square \mathrm{E} \diamond \mathrm{O}-4$
[328] A $\square \mathrm{E} \square \mathrm{O}-4$
$[331] \square \mathrm{A} \diamond \mathrm{EO}-4$
[334] $\square$ AEO-4

$[323] \square \mathrm{A} \square \mathrm{E} \diamond \mathrm{O}-4$
$[326] \square \mathrm{A} \square \mathrm{EO}-4$
$[329] \diamond \mathrm{AE} \diamond \mathrm{O}-4$
$[332] \square \mathrm{AE} \diamond \mathrm{O}-4$
$[335] \mathrm{A} \square \mathrm{EO}-4$

Theorem 30: The following modal syllogisms obtained by adding modal operators to the valid classical syllogism EAO-4 are valid:
[337] $\square \mathrm{E} \square \mathrm{A} \square \mathrm{O}-4$
$[340] \square \mathrm{E} \diamond \mathrm{A} \diamond \mathrm{O}-4$
$[338] \diamond \mathrm{E} \diamond \mathrm{A} \diamond \mathrm{O}-4$
[341] $\diamond \mathrm{E} \square \mathrm{A} \diamond \mathrm{O}-4$
[344] $\mathrm{E} \square \mathrm{A} \square \mathrm{O}-4$
[343] $\square \mathrm{EA} \square \mathrm{O}-4$
[347] $\square \mathrm{E} \diamond \mathrm{AO}-4$
[349] E $\square \mathrm{A} \diamond \mathrm{O}-4$
$[350] \square$ EAO-4
[339] $\nabla \mathrm{E} \square \mathrm{A} \diamond \mathrm{O}-4$
[342] $\square \mathrm{E} \square \mathrm{AO}-4$
[345] $\diamond \mathrm{EA} \diamond \mathrm{O}-4$
[348] $\square \mathrm{EA} \diamond \mathrm{O}-4$
[351] E $\square$ AO-4
[352] EA $\diamond \mathrm{O}-4$

Theorem 31: The following modal syllogisms obtained by adding modal operators to the valid classical syllogism EIO-4 are valid:
[353] $\square \mathrm{E} \square \mathrm{I} \square \mathrm{O}-4$
$[356] \square \mathrm{E} \diamond \mathrm{I} \diamond \mathrm{O}-4$
[359] $\square \mathrm{EI} \square \mathrm{O}-4$
$[362] \mathrm{E} \diamond \mathrm{I} \diamond \mathrm{O}-4$
$[365] \mathrm{E} \square \mathrm{I} \diamond \mathrm{O}-4$
[368] EI $\diamond \mathrm{O}-4$

$[354] \diamond \mathrm{E} \diamond \mathrm{I} \diamond \mathrm{O}-4$
$[357] \diamond \mathrm{E} \square \mathrm{I} \diamond \mathrm{O}-4$
$[360] \mathrm{E} \square \mathrm{I} \square \mathrm{O}-4$
$[363] \square \mathrm{E} \diamond \mathrm{IO}-4$
$[366] \square \mathrm{EIO}-4$

$[355] \square \mathrm{E} \square \mathrm{I} \diamond \mathrm{O}-4$

[358] $\square \mathrm{E} \square \mathrm{IO}-4$

[361] $\diamond \mathrm{EI} \diamond \mathrm{O}-4$

$[364] \square$ EI $\diamond$ O-4

[367] E $\square$ IO-4

Theorem 32: The following modal syllogisms obtained by adding modal operators to the valid classical syllogism IAI-4 are valid: 


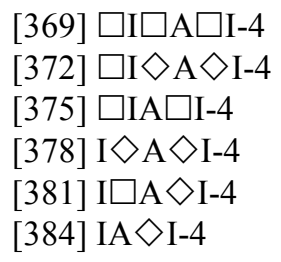

The validity of the above 384 Aristotelian modal syllogisms can be proved by means of the possible world semantics and the truth definition of Aristotelian quantifiers defined in generalized quantifier theory. That is to say, similar to the proof for Theorem 1-8, the validity of these syllogisms can be proved by Definition 1 and Definition 3 .

\section{Conclusion and the Future Work}

This paper has proven the validity of some Aristotelian modal syllogisms and shown how to screen out 384 Aristotelian valid modal syllogisms from 6656 Aristotelian modal syllogisms in natural language. Aristotelian modal syllogisms can be formalized on the basis of set theory and generalized quantifier theory, and their validity can be proved by making full use of possible world semantics and the truth definition of Aristotelian quantifiers defined in generalized quantifier theory. The basic steps of screening out all valid Aristotelian modal syllogisms are as follows: one can firstly get all possible modal syllogisms obtained by adding modal operators to 24 valid classical syllogisms, and secondly eliminate invalid modal syllogisms by the characteristic Rule 4 and Rule 5 of modal syllogisms.

In fact, these innovative achievements and the methods in this paper provide a simple and reasonable mathematical model to study generalized modal syllogisms. It is hoped that the present study will make contributions to promote the development of Aristotelian and generalized modal syllogistic logic, natural language information processing, and further research on knowledge representation and knowledge reasoning in computer science. Although the paper has screened out all Aristotelian valid modal syllogisms, can one take some valid syllogisms as the basic axioms and deduce all the other valid syllogisms? In other words, is there possible to axiomatize them? These questions need further study.

\section{Acknowledgements}

This work was supported by the National Social Science Foundation of China under Grant No. 19FZXB102.

\section{References}

[1] G. Patzig, Aristotle's Theory of the Syllogism, J. Barnes (trans.), Dordrecht: D. Reidel, 1969.

[2] J. Martin, Aristotle's natural deduction reconsidered, History and Philosophy of Logic Vol. 18, No. 1, 1997, pp. 1-15.

[3] L. S. Moss, Completeness theorems for syllogistic fragments, in F. Hamm and S. Kepser (eds.), Logics for Linguistic

\author{
[371] $\square \mathrm{I} \square \mathrm{A} \diamond \mathrm{I}-4$ \\ [374] $\square \mathrm{I} \square \mathrm{AI}-4$ \\ $[377] \diamond \mathrm{IA} \diamond \mathrm{I}-4$ \\ [380] $\square \mathrm{IA} \diamond \mathrm{I}-4$ \\ [383] I $\square$ AI-4
}

Structures, Berlin: Mouton de Gruyter, 2008, pp. 143-173.

[4] L. S. Moss, Syllogistic logics with verbs, Journal of Logic and Computation, Vol. 20, No. 4, 2010, pp. 947-967.

[5] L. S. Moss, Syllogistic Logic with Cardinality Comparisons, Springer International Publishing, 2016.

[6] P. Murinová, and V. Novák, A formal theory of generalized intermediate syllogisms, Fuzzy Sets and Systems, Vol. 186, No. 1, 2012, pp. 47-80.

[7] N. Ivanov, and D. Vakarelov, A system of relational syllogistic incorporating full Boolean reasoning, Journal of Logic, Language and Information, Vol. 21, No. 4, 2012, pp. 433-459.

[8] I. Pratt-Hartmann, The relational syllogistic revisited, Perspectives on Semantic Representations for Textual Inference, CSLI Publications, 2014, pp. 195-227.

[9] J. Endrullis, and L. S. Moss, Syllogistic logic with 'most', in V. de Paiva et al. (eds.), Logic, Language, Information, and Computation: 2015, pp. 124-139.

[10] Baoxiang Wu, Aristotel's Syllogisms and its Extensions, Sichuan Normal University, Master's Dissertation, 2017. (in Chinese)

[11] N. Chater, and M. Oaksford, The probability heuristics model of syllogistic reasoning, Cognitive Psychology, Vol. 38, No. 2, 1999, pp. 191-258.

[12] M. Malink, A reconstruction of Aristotle's modal syllogistic, History and Philosophy of Logic, Vol. 27, No. 2, 2006, pp. 95141.

[13] S. K. Thomason, Semantic Analysis of the Modal Syllogistic, Journal of Philosophical Logic, Vol. 26, No. 2, 1993, pp. 111128.

[14] S. K. Thomason, Relational model for the modal syllogistic, Journal of Philosophical Logic, Vol. 26, No. 2, 1997, pp. 1291141.

[15] P. Thom, The Logic of Essentialism: An Interpretation of Aristotle's Modal Syllogistic, (Synthese Historical Library 43), Dordrecht: Kluwer, 1996.

[16] F. Johnson, Models for modal syllogisms, Notre Dame Journal of Formal Logic, Vol. 30, No. 2, 1989, pp. 271-284.

[17] F. Johnson, Aristotle's modal syllogisms, Handbook of the History of Logic, Vol. 1, 2004, pp. 247-307.

[18] M. Malink, Aristotle's Modal Syllogistic, Cambridge, MA: Harvard University Press, 2013.

[19] J. van Benthem, Questions about quantifiers, Journal of Symbol Logic, Vol. 49, No. 2, 1984, pp. 443- 466.

[20] D. Westerståhl, Aristotelian syllogisms and generalized quantifiers, Studia Logica, Vol. XLVII, No. 4, 1989, pp. $577-585$. 
[21] Xiaojun Zhang, A Study of Properties of Generalized Quantifiers, PhD. dissertation, Chinese Academy of Social Sciences, 2011. (in Chinese)

[22] Xiaojun Zhang, Research on Generalized Quantifier Theory, Xiamen: Xiamen University Press, 2014. (in Chinese)

[23] Xiaojun Zhang, and Sheng Li, Research on the formalization and axiomatization of classical syllogisms, Journal of Hubei University (Philosophy and social sciences), Vol. 43, No. 6, 2016, pp. 32-37. (in Chinese)

[24] Xiaojun Zhang, Axiomatization of Aristotelian syllogistic logic based on generalized quantifier theory, Applied and Computational Mathematics, Vol 7, No. 3, 2018, pp. 167-172.
[25] S. Peters, and D. Westerståhl, Quantifiers in Language and Logic, Oxford: Claredon Press, 2006.

[26] Xiaojun Zhang, Research on Chinese Anaphora Resolution and its Reasoning Mode, Beijing: People's Publishing House, 2018.

[27] D. Westerståhl, Quantifiers in formal and natural languages, in D. M. Gabbay and F. Guenthner (eds.), Handbook of Philosophical Logic, Vol. 14, 2007, pp. 227-242.

[28] A. Chagrov, and M. Zakharyaschev, Modal Logic, Oxford: Clarendon Press, 1997.

[29] B. F. Chellas, Modal Logic: an Introduction, Cambridge: Cambridge University Press, 1980. 